\title{
The Influence of Antivaccination Movements on the Re-emergence of Measles
}

\section{Calderón Rodríguez Nelly Patricia ${ }^{1}$, Jerez Pacheco Yary Zulay ${ }^{1}$, Ruvalcaba Ledezma Jesús Carlos ${ }^{2}$, Chavarría Miranda Alejandra ${ }^{3}$, Jiménez Sánchez Reyna Cristina ${ }^{4}$ and Reynoso Vázquez Josefina ${ }^{5 *}$}

'Department of Public Health [ICSa-UAEH] Institute of Health Sciences-Autonomous University of the State of Hidalgo, Pachuca, Mexico. ${ }^{2}$ Department of Medicine, Master in Public Health and PhD. In Foods Sciences an Human Health in [ICSa-UAEH]. ${ }^{3}$ Department of Public Health [Instituto Elise Freinet] and [SSH] Health Services of Hidalgo, Pachuca, Mexico. ${ }^{4}$ Department of Nursing in [ICSa-UAEH]. ${ }^{5}$ Department of Pharmacy and Master in Public Health [ICSa-UAEH] Institute of Health Sciences-Autonomous University of the State of Hidalgo, Pachuca, Mexico.

\begin{abstract}
Measles is a contagious disease, preventable by vaccination, of great importance for public health and its impact on the morbidity and mortality of the population; particularly in America where there continue to be cases in unvaccinated persons, after having been declared in $\mathbf{2 0 0 2}$ by the WHO as a region free of this disease. To examine the epidemiological panorama of measles and the influence that anti-vaccinal movements have had on the elimination of the virus, through a bibliographic review to specify why this is a re-emerging disease. A systematic review was made in the SciELO database, Redalyc, EBSCO, PubMed. The incorporation of the vaccine for measles reduced the morbidity and mortality caused by this disease, Yet factors such as antivaccine movements have always contribututed to cases in regions where the disease was considered eradicated. Antivaccination movement are associations of people who oppose vaccination for different reasons, which represent one of the factors that prevent diseases such as measles from being eradicated from the population.
\end{abstract}

Keywords: Measles, reemerging, vaccine, anti-vaccine movement.

\footnotetext{
*Correspondence: Master in public Health. Josefina Reynoso Vázquez. Email: jreynoso@uaeh.edu.mx ICSA. Ex Inland revenue La Concepción, n / n; Pachuca-Actopan Highway, Tilcuautla Highway. Pachuca Hidalgo, Mexico. Tel (771) 1327538 ext. 4311. Tel movil. 5548817657.
}

(Received: 30 September 2018; accepted: 10 November 2018)

Citation: Calderón Rodríguez Nelly Patricia, Jerez Pacheco Yary Zulay, Ruvalcaba Ledezma Jesús Carlos, Chavarría Miranda Alejandra, Jiménez Sánchez Reyna Cristina and Reynoso Vázquez Josefina, The Influence of Antivaccination Movements on the Re-emergence of Measles, J Pure App/ Microbiol., 2019; Vol. 13(1):127-132 doi: 10.22207/JPAM.13.1.13

(C) The Author(s) 2019. Open Access. This article is distributed under the terms of the Creative Commons Attribution 4.0 International License which permits unrestricted use, sharing, distribution, and reproduction in any medium, provided you give appropriate credit to the original author(s) and the source, provide a link to the Creative Commons license, and indicate if changes were made. 


\section{INTRODUCTION}

Measles is one of the most contagious viruses (90\%) that are known, it is an RNA virus of the paramyxoviridae family; before the vaccine there were 100 million cases and more than 2 million deaths a year in the world during late childhood. With the introduction of the vaccine in 1963, the morbidity and mortality figures were significantly reduced. ${ }^{1}$

The majority of measles deaths (close to $98 \%$ ) occur in developing countries, being one of the deadliest childhood diseases, because it causes more infant deaths than any other disease preventable by vaccination. ${ }^{2}$

The measles virus can cause various complications associated with pneumonia, diarrhea and malnutrition. It can also produce, especially in developing countries, permanent disabilities such as brain injuries, blindness and deafness. $^{2}$

By the year 2000, the United States declared measles eliminated from the country, followed by this statement in 2002, according to the Pan American Health Organization (PAHO), it was eliminated from the Americas. However, it continues to be one of the leading causes of death in young children. , for 2016, 89,780 deaths were calculated for this cause, most of them in children under 5 years. ${ }^{3}$

In 2015 there was an outbreak in Disneyland in California, from which 118 cases were declared, mostly in the unvaccinated population, for this same year in Chile 193 suspected cases were notified, of these 146 were discarded, 42 were pending and 6 cases were confirmed establishing an outbreak. ${ }^{4}$ In Mexico, during 2011, three imported cases were detected. The above figures indicate that although vaccination in children has been the most effective preventive measure for measles, it continues to be a re-emerging disease since the first epidemics occurred in the Roman Empire and in China 1800 years ago, being isolated for the first time by Enders and Puebles in 1954, to the present. ${ }^{5}$

\section{Methodology}

A systematic review was carried out in the SciELO, Redalyc, EBSCO, PubMed databases; considered the key words: emerging and reemerging diseases, measles and vaccines with the aim of analyzing the epidemiological panorama of measles and the influence that anti-vaccinal movements have had on the elimination of the virus, through a bibliographic review, to specify why this is considered a reemerging disease.

\section{Epidemiological overview}

Measles was described as a clinical entity 1900 years ago, although it was confused with other exanthematic diseases, mainly smallpox; Rhacés, Persian physician of the tenth century, wrote the first clinical description of the disease. ${ }^{6}$

In 1676 Thomas Sydenham definitively identified the disease which he named: Febris Scarlatinae or Escarlatina Simplex, because at first according to his observations only consisted of a rash and he assumed that scarlet fever "barely deserved the name of disease". 15 years later, he had the conviction that he could produce severe and malignant forms that "were not inferior to a plague". $^{7}$

In 1846, Peter Panum, a young physician who was sent to help in an epidemic in the Faroe Islands in 1846, confirmed that measles was contagious and transmitted from person to person. In 1883, Hirsch described a devastating impact on the virgin populations of the Fiji Islands and the Amazon basin, a mortality rate of over $20 \%$ and the elimination of entire tribes was recorded. ${ }^{6}$

In this way, before the introduction of the vaccine, measles occurred frequently in childhood, at 20 years of age more than $90 \%$ of the world population had suffered it and, due to its global endemic behavior, produced epidemics of large proportions every two years or three years. According to WHO in the 1960s, it caused 130 million cases and 2.6 million deaths worldwide. ${ }^{8}$

The incorporation of the vaccine for measles significantly reduced the morbidity and mortality caused by this disease, however, constantly reemerging, in the year 2000 it is estimated that there were 39,9 million cases worldwide, 777,000 deaths and 28 million disability-adjusted life year (DALY). ${ }^{9}$

In November 2002, the Americas' region, 8 years after having set the goal of eliminating measles, announced that it had managed to interrupt its transmission, for this it included well-defined vaccination activities with a high and sustained coverage of more than $90 \% .^{10}$

Although for 2008 mortality from measles decreased by $90 \%$ due to the vaccination 
of 700 million children, from 9 months to 14 years; the greatest benefits were for the Eastern Mediterranean regions (a reduction of $9 \%$ was achieved) and for Africa, (decreased by $89 \%)^{11}$. In the United States, 131 cases of measles were reported, a figure that almost doubles the cases presented in the 2000-2007 period (63 cases per year) of which $91 \%$ belonged to people who were not vaccinated or their vaccination status was unknown, likewise $89 \%$ were imported from other countries mainly Europe. ${ }^{12}$

In 2013 there were 145,700 deaths due to measles worldwide, this means 400 deaths per day and 16 per hour, in 2015 in Colombia, Peru and Mexico there was 1 imported case, in the United States 87 and in Canada 168. ${ }^{13}$

In the week 19 of 2017, 115 cases of measles were confirmed in three countries of the Region of the Americas; United States of America (72), Canada (40) and Argentina (3), which exceeds the number of confirmed cases throughout 2016. The cases that occurred in both years correspond to cases imported or related to imports. ${ }^{14}$

In March 2018 in Colombia, two cases of measles were confirmed in the departments of Antioquia and Risaralda, imported from Venezuela by unvaccinated persons. By January of this year, Venezuela had 135 confirmed cases. ${ }^{15}$

In Venezuela, from the confirmation of the first case of measles in epidemiological week 26 of 2017 to epidemiological week 4 of 2018, 1,703 suspected cases of the disease were notified, of which 952 were confirmed, 751 were discarded; $82 \%$ of the cases were reported in Ciudad Bolívar. The most affected age group among the confirmed cases corresponds to children under 5 year olds, with $59 \%$ of confirmed cases, followed by the group of 6 to 15 years with $30 \%$ of confirmed cases. 15

In Guatemala, on March 19, 2018, after 20 years without cases of measles in the country, an imported one was confirmed, corresponding to a 17 -year-old person who visited Germany between October 2017 and January 2 of 2018. ${ }^{15}$

In Mexico before the 50s, measles was one of the main morbidity and mortality causes, later thanks to the availability of vaccines the behavior of the disease was modified, from 1941 to 1971 biannual epidemics appeared, in 1973 it appeared every four years, however, in 1989, an epidemic suddenly appeared in which 20381 cases were registered with a rate of 24.2 per 100 thousand inhabitants; in 1990 there were 68,782 cases with a rate of 82.5. ${ }^{16}$

Because this, in 1991 the 2 dose regimen vaccination was implemented: a first dose in the year and it was reinforced at 6 years of age, which reduced the incidence from 80.2 in 1990 to 0.14 in 1994.2; in the year 2000 there are 28 cases in children under 12 years unvaccinated. ${ }^{5}$

As of 1995 there is no case that has been self-controlled and since 1996 there are no endemic cases of measles, however, from 1997 to 2017 a total of 176 cases have been reported, all classified as imported or associated with the import. ${ }^{14}$

For epidemiological week 7 of 2018 , a probable case of measles imported from Baja California was identified by a 38-year-old woman from Tijuana. ${ }^{15}$

Factors associated with the re-emergence of measles

The main issue is, however, also, the state of greatest notoriety, among them, the demographic growth, and the growth of urban areas, migrations to cities or to developed countries in which immigrants or emigrants can be reservoirs of agents that that did not exist or had already been eliminated; international trade; quick easy access to information and misinterpretation of it, the latter has been one of the factors that has taken hold in the appearance of groups that for different reasons don't want their children to be vaccinated, those groups are called antivaccination movements. ${ }^{17}$

Anti-vaccination movements are made up of parents of children affected by certain neurological conditions of a chronic nature and unknown etiology ${ }^{18}$, who in their legitimate desire to know the cause of the condition of their children and hoping to offer some therapy, support the existence of a causal association, between the administration of a given vaccine and the development of a neurological condition, promoting non-vaccination and thus affecting herd immunity in the community.

"Anti-vaccination" movements gained momentum in the United States and have spread slowly to Mexico, especially since 1998, when a study by British physician Andrew Wakefield ${ }^{19}$ 
published in The Lancet linked the MMR vaccine - which is administered for immunization against measles, mumps and rubella - to autism.

Subsequent medical research showed that Wakefield's conclusions lacked scientific basis, but the damage was already done. The Lancet magazine in 2004 retracted completely from the article it had published in 1998, noting that the work data had been falsified. ${ }^{20}$

In general these groups could also be defined as a group of people who for different reasons (health, religious, scientific, political, philosophical) believe that vaccines and ultimately the act of vaccination is a greater harm to their health than the possible benefit that can contribute. ${ }^{21}$

Some of the myths on which these types of movements are based are ${ }^{22}$ :

1. Vaccination can cause autism: this statement arose from the study published in The Lancet by the English physician Andrew Wakefield in 1998 where it suggests that the measles, rubella and mumps vaccine could trigger autism, however, in 2004 it was discovered that Wakefield had conflicts of interest because he had applied for the patent for his own measles vaccine and had received money from a lawyer who was trying to sue the companies that produced the rubella, measles, and mumps vaccine. Today there are studies such as those published in Vaccine and Journal of the American Medical Association that have reported that there are no differences between the rates of autism among thousands of vaccinated and unvaccinated children.

2. Mercury in vaccines acts as a neurotoxin: in 2001 this component of childhood vaccines in the United States of America had already been eliminated, except for multidose flu, despite this the autism figures did not decrease which shows that there is no relationship of the presence of autism with thiomersal, in addition, the rumor that in Denmark the causes of autism due to the removal of thiomersal from vaccines in 1992 decreased is not true, according to the Center for Control and Prevention of Diseases (CDC, for its acronym in English), this was due to a misinterpretation of epidemiological data.

3. Counteracting mercury can improve children: In the mid-2000s, a Maryland doctor, Mark Geier and his son David (a graduate in arts) established an unapproved treatment to "counteract thiomersal damage" using leoprolide, a drug used to treat prostate cancer and chemical castration in sex offenders, which in children is only approved for the management of precocious puberty with side effects such as bone, heart and exacerbation of seizure disorders. The Geiers tried to trick the parents by saying that their treatment was approved, to sell it for a cost exceeding $\$ 5000$ per month. The board of doctors of Maryland and later other states revoked the medical license of Mark Geier and his son was accused of practicing medicine without a license.

4. Delaying vaccines may be safer for children: Some vaccine skeptics argue that vaccination before two years generates an overload in the immune system that would leave children prone to a lot of disorders, including delays in neurological development and diabetes. Experts strongly reject this claim because the child's immune system must deal with thousands of foreign antigens every day, while vaccination exposes the child up to 2 years to only 300 antigens approximately.

A qualitative study conducted in the province of Granada, Spain, of people who chose not to vaccinate their children, ${ }^{23}$ shows that these parents focus their responsibility on the individual well-being of their children and the right to parenting without interference from the state, regardless of the consequences that their action or omission entails to the community, and they raise the risks derived from vaccinating over the individual and collective consequences of not doing so.

Due to growing concern about the rejection of vaccines, the World Health Organization, the CDC and medical associations have issued technical guidelines and manuals on the subject. These documents present the causes, reinforce the consequences and suggest strategies to control vacillation or rejection, as well as establishing principles for health professionals to provide answers when faced in public with antivaccination movements. ${ }^{24}$

WHO and PAHO recommend vaccination to maintain $95 \%$ homogeneous coverage with the first and second doses of measles, rubella and mumps vaccine (MMR) in all municipalities ${ }^{25}$, yet there are obstacles that prevent from achieving 
that goal and although in American countries, most cases that have appeared in recent years are imported cases (except Venezuela as specified above), in European countries, studies have shown that most of those recent cases correspond to unvaccinated. In 2014, a total of 3,616 cases of measles were reported in 30 countries belonging to the European Union ${ }^{18}$, of the total number of cases with information based on vaccination records, $83 \%$ corresponded to unvaccinated, a figure that rose to $75 \%$ in children from 1 to 4 years.

With the analysis of the epidemic that occurred in the Valencian community (Spain) between 2011 and $2012^{26}$ where a total of 976 confirmed cases were reported, it was established that the proportion of unvaccinated subjects was $55 \%$, which together with those of unknown vaccination status, reached $85 \%$ of all cases.

Although there are also cases of measles in people with the recommended doses of vaccination ${ }^{27}$, most of the cases occur in people who are not vaccinated, as it has been reported, whether they be indigenous or imported, therefore, it is necessary to increase efforts to combat myths regarding vaccination and increase access to reliable information on the safety of vaccines currently used, for both health personnel to parents and in all media they have access to.

\section{CONCLUSIONS}

Vaccines represent the main way to prevent infectious diseases, reducing the morbidity and mortality of infectious diseases, being the most effective therapeutic intervention in terms of the cost-benefit ratio in the control of these diseases.

Measles is a viral disease that until a certain point in history was well controlled, thanks to good vaccination coverage in several developed countries, currently the measles virus continues to circulate and antivaccination movements have become a threat for its elimination and eradication and other diseases, hence it is required to create new strategies to expand vaccination coverage, demystify these plans and provide the necessary information through all media, ie to develop an approach aimed at generating confidence, as well additional and substantial investments are needed to strengthen health systems and achieve equitable access to vaccination services.

In regards to antivaccination movements we can conclude that going to extremes will always be negative whether it come from antivaccination fundamentalism or from pro-vaccine fanaticism, and the certainty that parents have about the complications generated by vaccines through different media mainly social networks, which is undoubtedly the medium where these groups disseminate information often wrong, is enough to counteract any scientific study, these movements are increasing and unfortunately the strategies used to reduce them have been ineffective.

The health personnel who play a fundamental role in the aspects surrounding immunization are undoubtedly the nursing staff where they develop a completely autonomous role, since they promote health and help to reinforce the self-responsibility of people with the activities that make them prevent diseases and preserve health.

\section{ACKNOWLEDGEMENTS}

The authors of the present research article would like to acknowledge and truly thank the collaboration of Yesenia Elizabeth Ruvalcaba Cobián for her contributions on the revision of the article.

\section{CONFLICT OF INTEREST}

The authors declares that there is no conflict of interest.

\section{REFERENCES}

1. Organización Mundial de la Salud. Fondo de las Naciones Unidas para la Infancia. Vacunas e inmunización: situación mundial. Ginebra, 1997: 42-7.

2. Muscat M, Ben-Mamou M, Shefer A, Jankovic D, Deshevoy S, Butler R. Situación del sarampión y la rubéola en la Región Europea de la OMS. Rev. Esp. Salud Pública. 2015; 89: 345-351.

3. Organización Mundial de la Salud. Actualización Epidemiológica Sarampión. 2018. [citado 2016 jul 18] Recuperado de: https://www.paho.org/hq/index. php?option=com_docman \&task=doc_view\&ltemid= $270 \&$ gid $=43509 \&$ lang $=$ es

4. Cuevas C, Contreras J, Rostion C, Mira M. Exantemas virales: Sarampión Cuevas Catalina. Rev. Ped. Elec. 2015; 12(2):718-918.

5. Wong-Chew RM. El sarampión. Conceptos actuales. Enf. Infec. Y Micro. 2003: 23(4): 133-136.

6. Carrada- Bravo MC, Velázquez-Diaz G. El impacto del sarampión en México. Sal. Púb. Méx. 1980; 359-408.

7. Lavar E. Thomas Sydenham y la individualización de la 
escarlatina. Rev. chil. 2003; 20(3): 215-217.

8. Delpiano L, Astroza L, Toro J. Sarampión: la enfermedad, epidemiología, historia y los programas de vacunación en Chile. Rev. chil. infectol. 2015; 32(4): 417-429.

9. Rota J, Lowe L, Rota P, Bellini W, Redd S, Dayan G, et al. Identical Genotype B3 Sequences from Measles Patients in 4 Countries, 2005. Emerg. Infect. Dis. 2006; 12(11): 1779-1781.

10. Organización Mundial de la Salud. Erradicación mundial del sarampión. 2010.[citado 2016 jul 18] Recuperado de: http://apps.who.int/gb/ebwha/ pdf_files/WHA63/A63_18-sp.pdf

11. Morón-Duarte LS, Castillo-Pabón JO. La vigilancia epidemiológica de sarampión y rubéola en el marco del plan de eliminación. Colombia 1995-2009. Revista de Salud Pública. 2012; 14(1):1-14.

12. Centers for disease control and prevention. Update: Measles United States,January. 2008. [citado 2016 jul 18] Recuperado de: https://www.cdc.gov/mmwr/ preview/mmwrhtml/mm5733a1.htm

13. Aparicio-Rodrigo M. Antivacunas: un reto para el pediatra. Rev. Pediatr. Aten. Primaria. 2015; 17(66): 107-110.

14. CONAVE. Aviso Epidemiológico 2017. 2017. [citado 2016 jul 18] Recuperado de: https://www.gob. $\mathrm{mx} / \mathrm{cms} / \mathrm{uploads} /$ attachment/file/226100/AE_ Sarampion_26052017.pdf

15. Organización Mundial de la Salud. Actualización Epidemiológica Sarampión. 2018 [citado 16 jul 18] Recuperado de: https://www.paho.org /hq/index. php? option $=$ com _ docman\&task $=$ doc_ view \&ltemid $=270$ \&gid $=45688$ \& lang $=$ es

16. Ferreira-Guerrero EE, Montesano R, Ruiz-Matus C. Panorama epidemiológico del sarampión en México. Gac. Méd. Méx. 132(1): 97-100.

17. Suárez-Larreinaga $C L$, Berdasquera-Corcho D. Enfermedades emergentes y reemergentes: factores causales y vigilancia. Rev. Cubana Med. Gen. Integr. 2000; 16(6): 593-597.

18. Cerda J, Abarca K, Jiménez J. Brotes de Sarampión en países desarrollados. Una lección para Chile. Rev. chil. infectol. 2015; 32(3): 326-328.

19. Wakefield AJ, Murch SH, Anthony A, Linnell J, Casson DM, Malik M, et al. Ileal-lymphoidnodular hyperplasia, non-specific colitis and pervasive developmental disorder in children. Lancet. 1998; 351: 637-41.

20. Jefferson T, Price D, Demicheli V, Bianco E. Selective quotation of evidence in vaccines research. Lancet. 2004; 363: 1738

21. López-Santamaria MA. Los movimientos antivacunación y su presencia en internet. Ene; 9(3).

22. Understanding Vaccines. [citado 2016 jul 18] Recuperado de: https://www. publichealth.org/ public-awareness /understanding-vaccines/ vaccinemyths-debunked/

23. Cruz-Piquerasa M, Rodríguez-García de Cortazar A, Hortal-Carmonac J, Padilla-Bernáldezd J. Reticencia vacunal: análisis del discurso de madres y padres con rechazo total o parcial a las vacunas. Gac. Sanit. 2017:1-7.

24. De Menezes-Succi RC. Vaccine refusal - what we need to know. J. Pediatr. (Rio J). 2018: 1-8.

25. Organización Panamericana de la Salud [Internet]. La OPS reitera su llamado a vacunar contra el sarampión para mantener su eliminación en las Américas; 2018 [ Citado 28 Mar de 2018]. Obtenido de http://www.paho.org/col/ index.php? option=com_ content\&view=article \&id=2923: la-ops-reiterasu-llamado-a-vacunar- contra-el-sarampionparamantener-su-eliminacion-en-las-americas \&ltemid $=487$

26. Guiral S, Guaita R, Rigo V, Amat M, Sierra M, Huertas I, et al. Reemergencia del sarampión. Situación epidémica en la Comunidad Valenciana durante los años 2011 y 2012. Enferm Infecc Microbiol Clin. 2014; 43-50.

27. Agut E, Gené E, Navarro G, \& González A. Reemergencia del sarampión en pacientes vacunados: descripción de seis casos y propuesta para su prevención. Emergencias. 2016; 182-184. 